\title{
Adhesion of staphylococci to polyurethane and hydrogel- coated polyurethane catheters assayed by an improved radiolabelling technique
}

\author{
STEPHANIE F. JOHN*, VALERIE F. HILLIER †, PAULINE S. HANDLEY* and M. R. DERRICK $\ddagger$ \\ * Department of Biological Sciences and † Computational Group, Stopford Building, Manchester University, \\ Oxford Road, Manchester M13 SPT and $\ddagger$ Ohmeda, Faraday Road, Dorcan, Swindon SN3 $5 \mathrm{JH}$
}

\begin{abstract}
Summary. Adhesion of Staphylococcus epidermidis NCTC 11047 to the external surface of polyurethane catheters was quantified by a radiolabelling assay. Maximum adhesion was achieved with an initial cell concentration of $3 \times 10^{8} / \mathrm{ml}$ after incubation for $120 \mathrm{~min}$. The assay was tested for reproducibility by analysis of variance. Adhesion of clinical strains of S. epidermidis and S. aureus to uncoated polyurethane and hydrogel (Hydromer ${ }^{\circledR}$ )-coated polyurethane catheters was compared. Hydrogel coating significantly reduced adhesion for both $S$. epidermidis and S. aureus (mean percentage reduction $71 \%$ for S. epidermidis, $69 \%$ for $S$. aureus). Clinical isolates were also tested for adhesion to polystyrene by a modified microtitration well adhesion assay; there was no correlation between staphylococcal adhesion to polyurethane catheters and adhesion to polystyrene. Cell surface hydrophobicity values varied widely for both species. Positive correlations were found between cell surface hydrophobicity and adhesion to polystyrene and uncoated polyurethane catheters for $S$. epidermidis but not for $S$. aureus.
\end{abstract}

\section{Introduction}

Nosocomial infections associated with intravascular catheters are increasing in parallel with the increased use of catheters in clinical practice. Between 1989 and 1991 , line-associated bacteraemias increased by $39 \%$ in the UK. ${ }^{1}$ The major causative organisms are the coagulase-negative staphylococci $(\mathrm{CNS})^{2-4}$ and Staphylococcus aureus, the latter being associated with more serious infections. ${ }^{5}$

Catheters are manufactured from many different materials, and bacterial attachment to these has been quantified in a number of studies. Lopez-Lopez et al. ${ }^{6}$ studied the attachment of single strains of $S$. aureus and $S$. epidermidis to polyvinylchloride, Teflon ${ }^{\circledR}$, siliconised latex, polyurethane and Vialon ${ }^{\circledR}$ catheters; polyurethane catheters supported the lowest level of adhesion. Pascual et al. ${ }^{7}$ quantified the attachment of 11 strains of CNS to Teflon ${ }^{\circledR}$ catheters; no other catheter materials were studied. Most hospitals now use polyurethane central venous catheters, some coated with a hydrophilic hydrogel (Hydrocath ${ }^{\mathbb{B}}$ ). Hydrogel was developed primarily for its haemocompatibility, which reduces the incidence of device- related thrombophlebitis. The hydrogel absorbs water immediately it comes into contact with blood. With the use of an ATP bioluminescence assay and viable counts, Kristinsson ${ }^{8}$ was unable to demonstrate a statistically significant reduction in the adhesion of $S$. epidermidis and $S$. aureus strains to Hydromer ${ }^{\circledR}$ coated, polyurethane catheters, when compared to uncoated catheters.

Adhesion assays with radiolabelled bacteria ${ }^{6,7,9,10}$ have the potential to quantify bacterial adhesion to biomaterials accurately, but reported methods have several limitations that impede accuracy and reproducibility; in particular, the limited number of replicates and the lack of relevant controls (see Discussion).

The hydrophobic properties of the bacterial cell surface play a significant role in the adhesion of bacteria to various substrata. For example, positive correlations have been found between bacterial hydrophobicity and adhesion to solid substrata in dental research, ${ }^{11}$ marine fouling ${ }^{12}$ and the adhesion of freshwater bacteria.$^{13}$ However, studies comparing the cell surface hydrophobicity of CNS and the adhesion to catheters have provided contradictory results, ${ }^{7,14}$ and the role of hydrophobicity in adhesion to biomaterials remains unclear.

This paper describes an improved quantitative adhesion assay based on tritiated-methyl-thymidine- 
labelled cells. The assay was used to study the effect of hydrogel coating on the adhesion of $S$. epidermidis and $S$. aureus to polyurethane catheters. The relationship between hydrophobicity and adhesion to polyurethane and polystyrene was also investigated.

\section{Materials and methods}

\section{Bacterial strains and growth conditions}

S. epidermidis NCTC 11047 was used as a control throughout the study. Eleven clinical strains of $S$. epidermidis were isolated by $M$. Howard (Manchester Royal Infirmary) from catheter tips (central venous catheters; umbilical arterial or venous catheters) from babies in the Special Care Baby Unit at the Manchester Royal Infirmary. S. epidermidis F337, isolated from a central venous catheter (CVC), was kindly donated by Dr R. Bayston (Nottingham City Hospital). S. aureus strains were isolated from CVC tips cultured at the Withington Hospital, Manchester. Identification of staphylococci was confirmed biochemically (API STAPH; bioMérieux. Basingstoke). Strains were stored at $-70^{\circ} \mathrm{C}$ and cultured on Tryptone Soya Broth (TSB; Oxoid) agar (to confirm purity) and then subcultured into TSB for $20 \mathrm{~h}$ at $37^{\circ} \mathrm{C}$ before use. For the adhesion assay, strains were grown in TSB containing tritiated methyl thymidine (Amersham, Bucks) $8 \mu \mathrm{Ci} / \mathrm{ml}$, with specific activity of $49 \mathrm{Ci} / \mathrm{mmol}$, for $20 \mathrm{~h}$; cells were washed three times in $0.05 \mathrm{M}$ Tris buffer, $\mathrm{pH} 7.5$. containing $0.145 \mathrm{M} \mathrm{NaCl}$ and resuspended in the same buffer to various concentrations (see below).

\section{Adhesion assay}

Sterile hydrogel-coated $(\mathrm{C})$ and uncoated $(\mathrm{U})$ polyurethane catheters (Ohmeda, Swindon) were cut into $1-\mathrm{cm}$ lengths with a fixed measurement cutting block. "Catheter assemblies" were constructed; these consisted of eight pieces of catheter held firmly together at the ends by two plastic holders, with projections fitting exactly the lumen of each catheter piece. For simultaneous comparison of bacterial adhesion to the two different catheter types, two catheter assemblies were used, each holding four pieces of $U$ and four pieces of $\mathrm{C}$ catheter, but arranged in different ways, alternating the positions of $C$ and $U$ catheters to minimise any effect of the positioning of the catheter on bacterial adhesion. Catheter pieces were drawn randomly from a large pool of pieces, to eliminate any differences that may have existed between the original whole catheters.

Catheter assemblies were submerged in $4 \mathrm{ml}$ of washed, radiolabelled cells, at various concentrations, in acid-washed glass universal bottles and incubated for various times. Bottles were agitated on a haemoplate shaker (Titertek, Flow Laboratories, Germany). Each assembly was then removed, washed three times in separate containers of distilled water and dismantled. Individual pieces were placed in scintillation vials containing $3.5 \mathrm{ml}$ of scintillation fluid (Ecoscint A; Mensura Technology Ltd, Wigan) and read in a scintillation counter (2000 CA Tri Carb Packard; United Technologies, Berks).

The percentage adhesion per catheter piece was calculated from the equation:

$$
\text { Adhesion }(\%)=\frac{\text { radioactivity } / \text { catheter piece }}{\text { initial radioactivity } / \mathrm{ml}} \times 100
$$

An estimate of the number of cells bound to each catheter piece was calculated from the equation:

$$
\begin{aligned}
& \text { Bound cells } / \text { catheter piece }= \\
& \frac{\text { initial cells } / \mathrm{ml}}{\text { initial radioactivity } / \mathrm{ml}} \times \text { radioactivity } / \text { catheter piece }
\end{aligned}
$$

\section{Optimum parameters for adhesion of $S$. epidermidis NCTC 11047}

To study the effect of bacterial concentration on adhesion, washed radiolabelled $S$. epidermidis NCTC 11047 cells were resuspended to a final $\mathrm{OD}_{440}$ of 0.5 $\left(5 \times 10^{8}\right.$ cells $\left./ \mathrm{ml}\right)$. A series of two-fold dilutions was made in Tris buffer, to give a range of bacterial concentrations $\left(10^{7}-5 \times 10^{8}\right.$ cells $\left./ \mathrm{ml}\right)$, which were confirmed by visual counts with a Helber chamber. Adhesion assays were performed, as described above, with an incubation period of $2 \mathrm{~h}$.

To study the effect of incubation time on adhesion, washed, radiolabelled $S$. epidermidis NCTC 11047 cells were resuspended in Tris buffer to $\mathrm{OD}_{440} 0.393$ (c. $3 \times 10^{8}$ cells $/ \mathrm{ml}$ ), and an acid-washed glass evaporating dish was used as the incubation vessel. Adhesion assays were performed as described, except that catheter assemblies were removed at various time intervals.

\section{Statistical analysis}

The reproducibility of the assay method was tested by comparing the adhesion of the same batch of radiolabelled $S$. epidermidis NCTC 11047 cells to U catheters in five separate bottles. Batch-to-batch variation was analysed by comparing adhesion to $\mathrm{U}$ and $C$ catheters (incubated in the same bottle) with different batches of radiolabelled cells.

Results were analysed with a nested model of analysis of variance (see Results).

\section{Microtitration plate assay}

Adhesion of S. epidermidis and S. aureus strains to polystyrene microtitration wells was quantified in a modification of the method developed by Christensen et al. ${ }^{15}$ Cultures were grown overnight $(20 \mathrm{~h})$ in TSB. Cells were washed in $0.05 \mathrm{~m}$ Tris buffer $(\mathrm{pH} 7.5$ ), containing $0 \cdot 145 \mathrm{M} \mathrm{NaCl}$, and resuspended in Tris buffer to $\mathrm{OD}_{440}$ of 0.393 . Each isolate $(100 \mu \mathrm{l})$ was added to each of eight wells of a 96-well microtitration plate (Costar, Cambridge, USA). Plates were incubated at $37^{\circ} \mathrm{C}$ for $2 \mathrm{~h}$, washed twice with buffer, and 


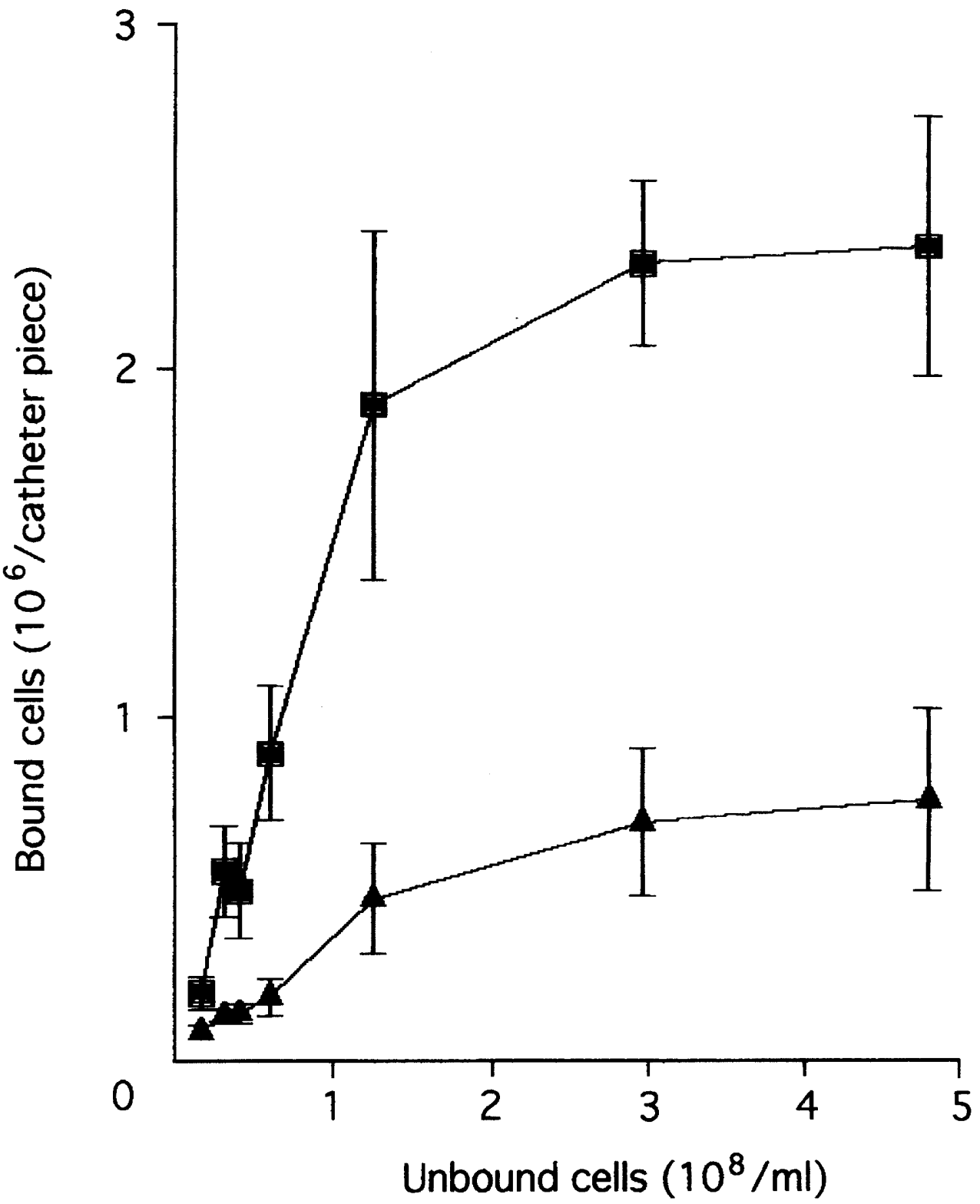

Fig. 1. Binding isotherm of S. epidermidis NCTC 11047 bound cells to both uncoated ( unbound cells in suspension. Each point represents the mean and SD of eight replicates.

inverted, to remove excess. Remaining attached cells were fixed with Bouin's fixative $(75 \mathrm{ml}$ of saturated aqueous picric acid; $25 \mathrm{ml}$ of formaldehyde $40 \% ; 5 \mathrm{ml}$ of acetic acid $99 \%$ ). Plates were stood for $30 \mathrm{~min}$, washed with Tris buffer and then stained with crystal violet $0.5 \% \mathrm{w} / \mathrm{v}, 100 \mu \mathrm{l} /$ well. Plates were stood for a further $30 \mathrm{~min}$ and then washed with tap water. The optical density of wells was determined with an ELISA plate reader (MR 7000 Dynatech) at a wavelength of $570 \mathrm{~nm}$. A row of eight wells, incubated with sterile broth only, was used as a control.

\section{Hexadecane partition assay}

This assay was performed according to the method of Rosenberg et al. ${ }^{16}$ Overnight cultures of each test strain were washed three times in Tris buffer and then resuspended to $\mathrm{OD}_{440} 0 \cdot 5$. Cell suspensions were distributed, in 3-ml volumes, into five test tubes and $200 \mu \mathrm{l}$ of hexadecane were layered on to each. Tubes were vortex mixed for $1 \mathrm{~min}$ and then left to stand for $1 \mathrm{~h}$, to allow for partitioning of the hexadecane and buffer. The lower aqueous phase was used to determine the $\mathrm{OD}_{440}$ of each sample, with buffer as a blank. The percentage affinity of the bacteria for the hexadecane was then calculated:

$$
\frac{\mathrm{OD}_{440} \mathrm{i}-\mathrm{OD}_{440} \mathrm{p}}{\mathrm{OD}_{440} \mathrm{i}} \times 100 \%
$$

where $\mathrm{OD}_{440} \mathrm{i}$ represents the $\mathrm{OD}$ of the initial suspension and $O D_{440} P$ represents the $O D$ of the partitioned suspension.

\section{Results}

\section{Reproducibility of adhesion assay}

The mean counts/catheter piece in each bottle were compared by analysis of variance. When $U$ catheters alone were incubated with the radiolabelled cells, some 


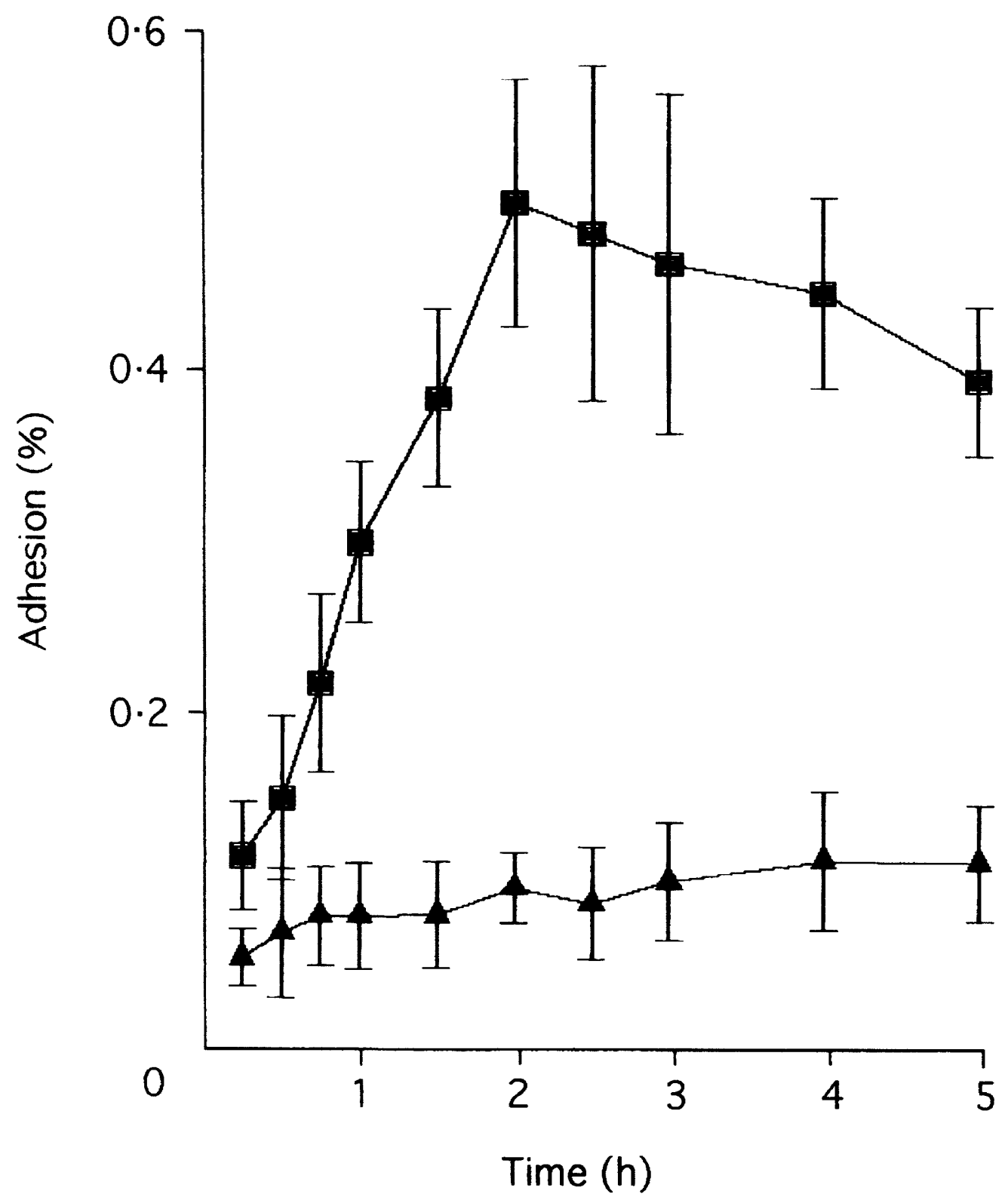

Fig. 2. Time course of $S$. epidermidis NCTC 11047 adhesion to both uncoated ( represents the mean and $\mathrm{SD}$ of eight replicates. for one experiment.

statistical differences in adhesion values between the five bottles were noted. To eliminate this difference, $\mathrm{C}$ and $U$ catheters had to be compared within the same bottle ("within bottle design"). This experimental design dictated a hierarchical analysis of the data, to eliminate any statistical differences between batches and bottles: this was performed with GLIM (Generalised Linear Modelling).

With this experimental design, the reproducibility of the adhesion values obtained from two separate batches of radiolabelled cells of S. epidermidis NCTC 11047 was tested (batch-to-batch variation). In some cases there was a statistically significant difference between adhesion values, obtained from different batches of cells. These differences were taken into account in the statistical analysis of the data for the full study.
Optimum parameters for the radiolabelling adhesion assay

Catheter pieces were incubated in cultures of $S$. epidermidis NCTC $11047,10^{7}-5 \times 10^{8}$ cells $/ \mathrm{ml}$ and incubated with the catheter pieces for $2 \mathrm{~h}$. The numbers of cells attached to the $\mathrm{U}$ and $\mathrm{C}$ catheters were calculated and plotted against initial cell concentrations in a binding isotherm (fig. 1).

Approximately four times as many cells bound to $\mathrm{U}$ catheters compared to $\mathrm{C}$ catheters. The number of adherent cells increased in parallel with the initial cell concentration up to a concentration of $3 \times 10^{8}$ cells $/ \mathrm{ml}$. Further increases in cell concentration had only a marginal effect on bacterial adhesion. A cell concentration of $3 \times 10^{8}$ cells $/ \mathrm{ml}$ was used in subsequent experiments.

Bacterial adhesion to $U$ catheters was maximal at $2 \mathrm{~h}$; further incubation resulted in a small decrease in 


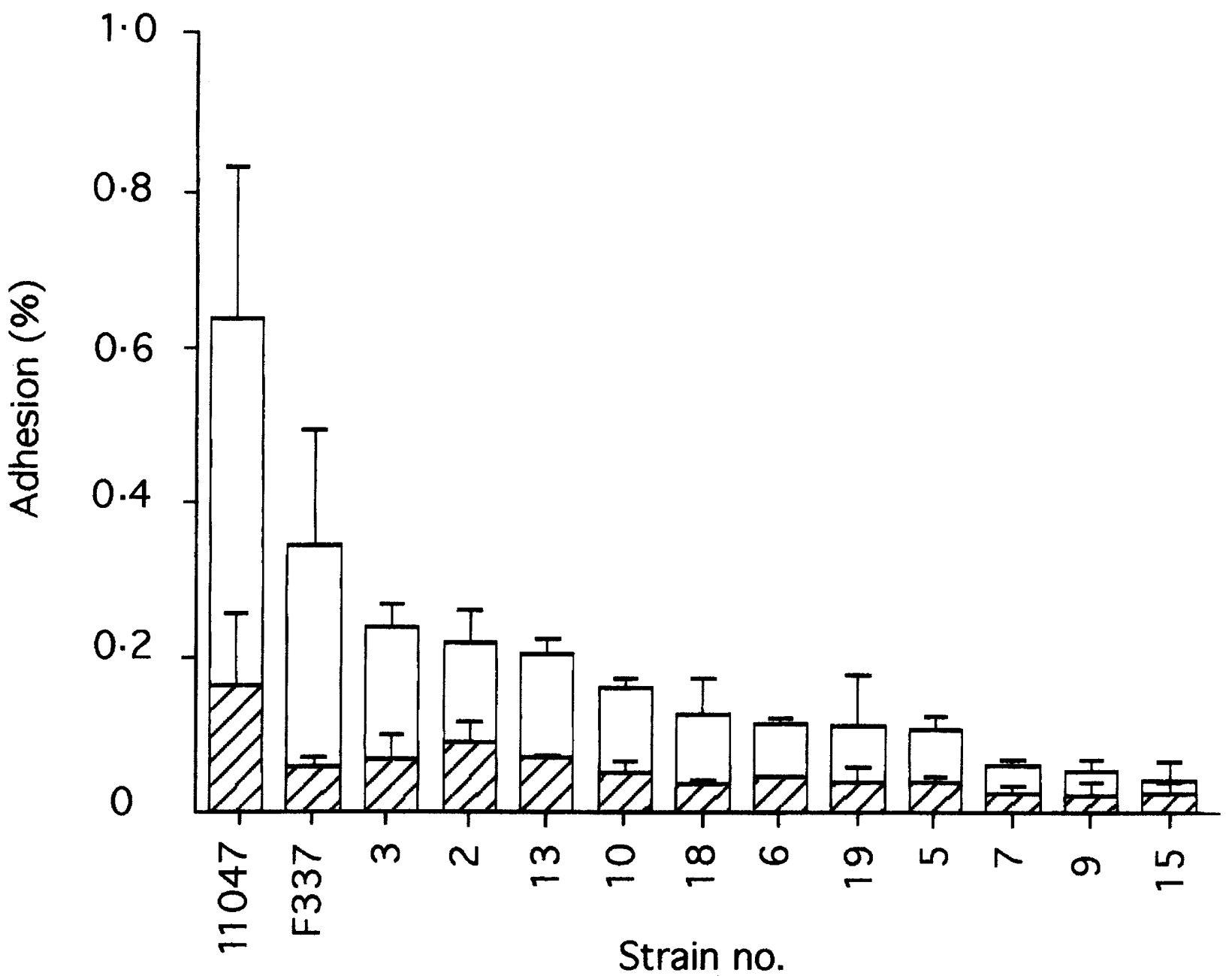

Fig. 3. Strain variation in adhesion of $S$. epidermidis strains to uncoated $(\square)$ and coated $(\square)$ catheters, in the radiolabelling assay. Each bar represents the mean and SD of two experiments and 16 replicates.

adherent cells. Bacterial adhesion to $\mathrm{C}$ catheters was poor and increased only marginally over the 5-h incubation period. Repeaied time course experiments (four repetitions) gave similar adhesion patterns, although actual percentage adhesion values varied considerably $(0.765-0.222 \%$, after $2 \mathrm{~h}$, for the $\mathrm{U}$ catheters) with each batch of cells (fig. 2).

\section{Adhesion of clinical isolates of S. epidermidis and $S$. aureus}

Adhesion of S. epidermidis and S. aureus strains to $\mathrm{C}$ and $\mathrm{U}$ catheters was compared (figs. 3 and 4). Each strain was tested in two separate experiments; on each occasion two catheter assemblies were tested (eight $\mathrm{C} /$ eight $\mathrm{U}$ catheters). For some strains, adhesion to catheters was significantly different when results for the two experiments were compared ( $S$. epidermidis strains 3, 2, 19, 5, 9 and 15 , and $S$. aureus strains SA10, SA14, SA20).

Both $S$. epidermidis and $S$. aureus strains adhered poorly to $\mathrm{C}$ catheters (mean adhesion value $0.055 \%$ for $S$. epidermidis, $0.127 \%$ for $S$. aureus). For U catheters, $S$. aureus strains (mean adhesion value $0.477 \%$ ) were more adherent than $S$. epidermidis strains, (mean adhesion value $0.188 \%$ ). When ad- hesion to $\mathrm{C}$ and $\mathrm{U}$ catheters was compared for all strains of each species, the hydrogel coating reduced the mean adhesion of $S$. aureus strains by $69 \%$ and $S$. epidermidis strains by $71 \%$. Taken individually, all staphylococcal strains tested were more adherent to U catheters although the difference was not statistically significant for some strains ( $S$. aureus SA8, SA9, SA15; S. epidermidis 6,18 ); figs. 3 and 4 give the unadjusted data (unadjusted for batch and bottle variation) for $\mathrm{C}$ and $\mathrm{U}$ catheter pieces and, therefore, do not always reflect exactly the results of the statistical analysis.

\section{Adhesion of staphylococci to polystyrene microtitration wells}

Adhesion of staphylococci to polystyrene was assessed by OD readings, following crystal violet staining (tables I and II). Strains are listed in order of decreasing adhesion to $U$ polyurethane catheters (data from figs. 3 and 4). S. epidermidis strains gave $\mathrm{OD}_{570}$ values of $0.077-0.176$ (table I) and $S$. aureus strains gave values of $0.097-0.201$ (table II). There was no significant correlation between adhesion to polyurethane and adhesion to polystyrene ( $\mathrm{r}=0.463$ for $S$. epidermidis strains; $\mathrm{r}=0 \cdot 153$ for $S$. aureus strains). 


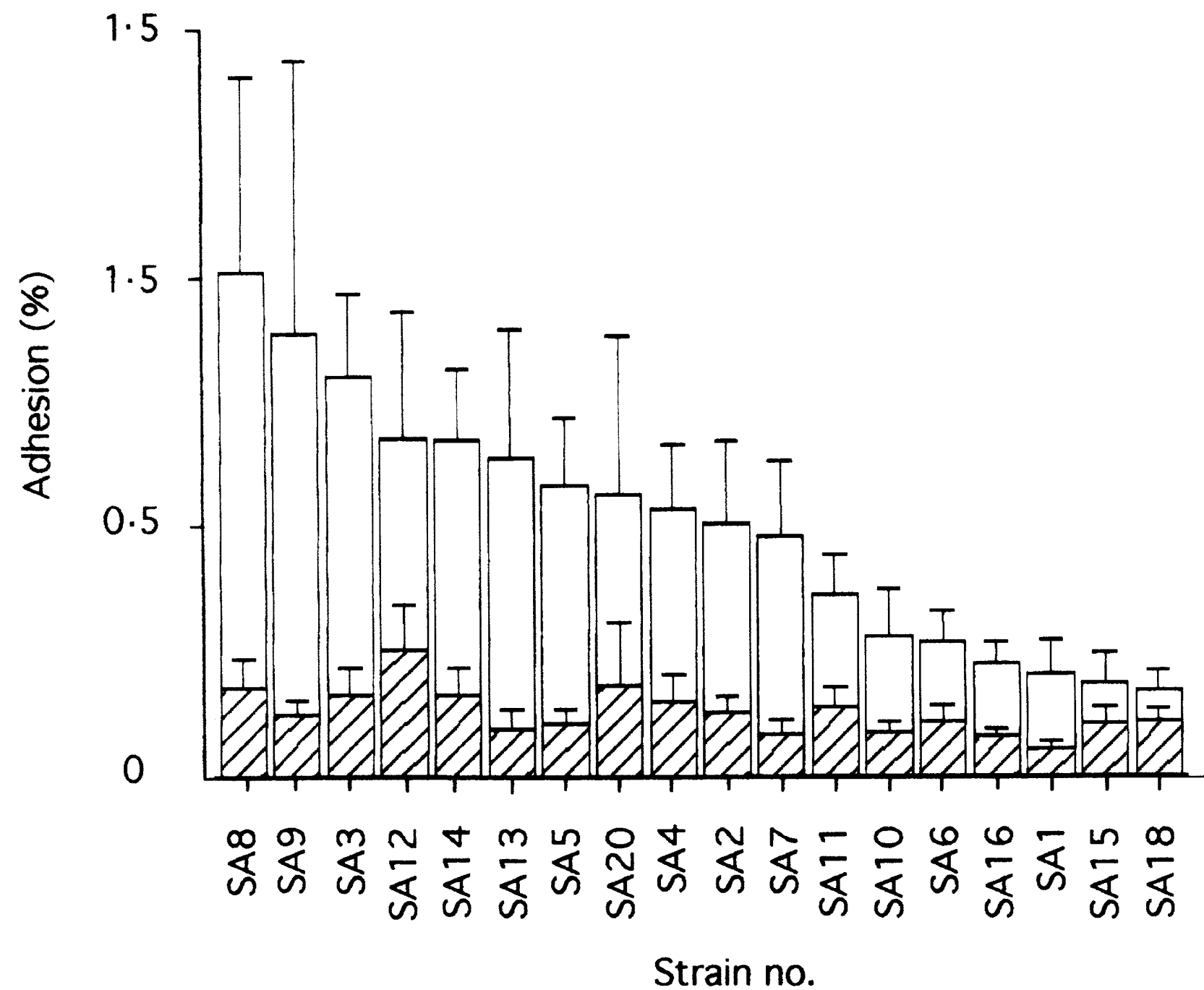

Fig. 4. Strain variation in adhesion of S. aureus strains to uncoated $(\square)$ and coated $(\square)$ catheters, in the radiolabelling assay. Each bar represents the mean and SD of two experiments and 16 replicates.

Table I. Adhesion of S. epidermidis strains to polystyrene wells and cell surface hydrophobicity $(\%)$

\begin{tabular}{|c|c|c|}
\hline Strain no. & $\begin{array}{c}\text { Mean (SD) adhesion } \\
\left(\mathrm{OD}_{550}\right)\end{array}$ & $\begin{array}{c}\text { Mean (SD) hydrophobicity } \\
\qquad(\%)\end{array}$ \\
\hline NCTC 11047 & $0.161(0.005)$ & $42.90(4.00)$ \\
\hline $\mathrm{F} 337$ & $0.165(0.011)$ & $51.90(8.40)$ \\
\hline 3 & $0.166(0.005)$ & $86.69(8.99)$ \\
\hline 2 & $0.175(0.006)$ & $83 \cdot 16(4.92)$ \\
\hline 13 & $0.176(0.005)$ & $82.93(4.71)$ \\
\hline 10 & $0.077(0.016)$ & $8.47(0.85)$ \\
\hline 18 & $0.106(0.015)$ & $7.01(0.73)$ \\
\hline 6 & $0 \cdot 113(0 \cdot 034)$ & $11.89(1.46)$ \\
\hline 19 & $0.122(0.025)$ & $7.71(0.91)$ \\
\hline 5 & $0.126(0.017)$ & $23.59(4.08)$ \\
\hline 7 & $0.170(0.021)$ & $50.45(8.06)$ \\
\hline 9 & $0.106(0.012)$ & $10.44(0.54)$ \\
\hline 15 & $0.109(0.018)$ & $9.33(0.93)$ \\
\hline
\end{tabular}

\section{Cell surface hydrophobicity}

A wide range of cell surface hydrophobicity values was found for both species, after each strain was tested twice $(7.086 .7 \%$ for $S$. epidermidis strains, table I; $9.2-85.5 \%$ for $S$. aureus strains, table II). There was a strong correlation $(r=0.913, p<0.01)$ between hydrophobicity and adhesion to polystyrene and a
Table II. Adhesion of $S$. aureus isolates to polystyrene wells and cell surface hydrophobicity $(\%)$

\begin{tabular}{|c|c|c|}
\hline $\begin{array}{l}\text { Strain } \\
\text { no. }\end{array}$ & $\begin{array}{c}\text { Mean }(\mathrm{SD}) \text { adhesion } \\
\left(\mathrm{OD}_{570}\right)\end{array}$ & $\begin{array}{c}\text { Mean (SD) hydrophobicity } \\
(\%)\end{array}$ \\
\hline 8 & $0.190(0.019)$ & $73 \cdot 00(2 \cdot 71)$ \\
\hline 9 & $0.176(0.019)$ & $47.09(3.06)$ \\
\hline 3 & $0.192(0.029)$ & $60.58(2.64)$ \\
\hline 12 & $0.123(0.014)$ & $29 \cdot 04(3.01)$ \\
\hline 14 & $0.126(0.019)$ & $39.89(2.88)$ \\
\hline 13 & $0.124(0.017)$ & $23.90(2.91)$ \\
\hline 5 & $0.194(0.017)$ & $26 \cdot 11(3 \cdot 72)$ \\
\hline 20 & $0.135(0.015)$ & $73.65(3.50)$ \\
\hline 4 & $0.201(0.020)$ & $35.29(7.43)$ \\
\hline 2 & $0.097(0.028)$ & $18 \cdot 41(1 \cdot 16)$ \\
\hline 7 & $0.168(0.022)$ & $54.57(3.49)$ \\
\hline 11 & $0.158(0.012)$ & $61.43(9.53)$ \\
\hline 10 & $0.165(0.010)$ & $85.53(3.30)$ \\
\hline 6 & $0.163(0.017)$ & $84 \cdot 20(2 \cdot 51)$ \\
\hline 16 & $0.149(0.011)$ & $69.26(3.69)$ \\
\hline 1 & $0.170(0.028)$ & $9 \cdot 20(0 \cdot 74)$ \\
\hline 15 & $0.113(0.034)$ & $21.32(4.96)$ \\
\hline 18 & $0 \cdot 148(0 \cdot 016)$ & $73 \cdot 79(2 \cdot 18)$ \\
\hline
\end{tabular}

weak correlation $(r=0.714, p<0.05)$ between hydrophobicity and polyurethane catheter adhesion for $S$. epidermidis strains. There was no correlation between the same parameters for the $S$. aureus strains. 


\section{Discussion}

A quantitative, radiolabelling adhesion assay showed that hydrogel coating on polyurethane catheters significantly reduced the adhesion of most $S$. epidermidis and $S$. aureus strains tested. The radiolabelling assay reported has advantages over previously published assays. ${ }^{6,7,10}$ Blocking the end of the catheter pieces prevented entrapment of unattached bacteria. Taking scintillation counts from eight separate pieces of catheter in each experiment increased the reliability of statistical analysis; numbers of replicates have been low in previous reports. The catheter assembly design separated catheter pieces, allowing the cell suspension to circulate freely for maximum interaction of cells with the catheter surface. However, the main advantage of this assay was the inclusion of uncoated and coated catheter pieces in the same bottle, so that the two materials were compared in an identical environment. Adoption of a standardised assay, such as the one proposed in this study, makes it possible to quantify adhesion to any new catheter material.

Adhesion of $S$. epidermidis NCTC 11047 to uncoated polyurethane reached a maximum after incubation for $2 \mathrm{~h}$. This contrasts with previous studies; $S$. epidermidis HUS41 showed maximum adhesion to uncoated polyurethane catheters after $24 \mathrm{~h},{ }^{6}$ whilst adhesion of both hydrophilic and hydrophobic strains of $S$. epidermidis to Teflon ${ }^{\circledR}$ catheters was still increasing after $18 \mathrm{~h}^{7}$ The reasons for these differences in adhesion kinetics are unclear, but may reflect a combination of factors, such as differing assay conditions, differences between surface properties of strains and variable physicochemical properties of the catheter material. For example, in the present study, adhesion kinetics of $S$. epidermidis NCTC 11047 to hydrogel-coated and uncoated polyurethane, differed markedly (fig. 2). Denyer et al. ${ }^{17}$ have shown that changes in the surface hydrophobicity of biomaterials can alter bacterial attachment significantly.

Attachment of S. epidermidis and S. aureus to plastic surfaces is mediated by non-specific adhesion processes, governed by the physicochemical properties of both the bacteria and the underlying substrata. ${ }^{18}$ The role of cell surface hydrophobicity as a non-specific binding factor in bacterial adhesion is generally accepted $^{19}$ and a positive correlation between bacterial hydrophobicity and adhesion to solid substrata has been found. ${ }^{20}$ However, the involvement of hydrophobicity in CNS adhesion to plastics is controversial. Some authors claim that there is no correlation between $S$. epidermidis cell surface hydrophobicity and adhesion to polymer materials, ${ }^{8,21,22}$ whereas another has found a positive correlation between the two parameters, indicating that hydrophobicity plays a powerful role in the adhesion of CNS to plastics. ${ }^{7}$ The cell surface hydrophobicity of $S$. epidermidis strains correlated with adhesion to polystyrene and to a lesser extent, polyurethane catheters. The adhesion assays and hexadecane assay were performed in the same buffer and the two adhesion assays were performed under identical conditions, enabling valid comparisons to be made.

In contrast, there was no correlation between cell surface hydrophobicity and adhesion to either polymer for $S$. aureus strains. The reasons for this difference are unclear. Both $S$. epidermidis and $S$. aureus strains showed a wide range of values for affinity to hexadecane, so the test was able to discriminate between strains of both species. Other factors such as surface charge, presence of capsular material or growth phase may be more significant than hydrophobicity in the adhesion of $S$. aureus to plastics. The hydrophobicity of $S$. aureus strains is known to depend on the growth medium ${ }^{23}$ and growth phase, ${ }^{16}$ factors that were not considered in this study.

The presence of the hydrophilic hydrogel reduced the adhesion of all strains, although this reduction was not statistically significant for a minority of strains of each species (e.g., S. aureus SA8 and SA9). Significant differences in adhesion between batches were often observed, but the reasons for this are unclear. Within each species, strain-to-strain variation in adhesion to hydrogel-coated catheters was less prominent than for uncoated catheters. The mean adhesion of $S$. aureus strains to coated catheters was twice that observed for S. epidermidis. Hydrogel solubilises only slowly (14\% loss over 28 days in buffer at $37^{\circ} \mathrm{C}$; M. Derrick, personal communication). Any small amounts of hydrogel solubilised and then adsorbed to uncoated pieces of polyurethane over the 2-h assay period would be unlikely to alter the statistically significant difference between adhesion to the two catheter types tested.

The hydrogel coating is very hydrophilic, indicating a high surface energy. Negatively charged, hydrophilic surfaces discourage bacterial adhesion ${ }^{12}$ and hydrogel is likely to prevent adhesion by electrostatic repulsion. This study presents further evidence that hydrogel reduces bacterial adhesion significantly. Our observations are supported by Denyer et $a l^{17}$ and Kristinsson, ${ }^{8}$ who used different assays and smaller numbers of strains. Kristinsson ${ }^{8}$ also observed bacteria on the surface of uncoated polyurethane catheters by scanning electronmicroscopy. In contrast, few bacteria were seen on hydrogel-coated catheters.

The cell surface hydrophobicity of $S$. epidermidis and $S$. aureus did not correlate with adhesion to the hydrogel, indicating that attachment to a high energy, hydrophilic surface is not governed solely by the hydrophobic nature of the bacterial surface and other factors are probably involved.

This work was funded by the BBSRC and Ohmeda. We thank Dr J. G. Cunniffe who confirmed the identification of the S. epidermidis clinical isolates with API strips. 


\section{References}

1. Elliott TSJ. Line-associated bacteraemias. Communicable Disease Report (CDR Review). 1993: 3: R91-R97.

2. Pfaller MA. Herwaldt LA. Laboratory, clinical, and epidemiological aspects of coagulase-negative staphylococci. Clin Microbiol Ret 1988: 1: 281-299.

3. Kloos WE, Bannerman TL. Update on clinical significance of coagulase-negative staphylococci. Clin Microbiol Rev 1994 7: $117-140$.

4. Goldmann DA. Pier GB. Pathogenesis of infections related to intravascular catheterization. Clin Microbiol Rer 1993; 6: $176-192$

5. Maki DG. Infections associated with intravascular lines. Curr Clin Top Infect Dis 1982: 3: 309 363

6. Lopez-Lopez G. Pascual A. Perea EJ. Effect of plastic catheter material on bacterial adherence and viability. $J \mathrm{Med}$ Microbiol 1991 : 34: 349-353

7. Pascual A. Fleer A, Westerdaal NAC, Verhoef $\mathbf{J}$. Modulation of adherence of coagulase-negative staphylococci to Teflon catheters in vitro. Eur J Clin Microbiol 1986; 5: 518-522

8. Kristinsson KG. Adherence of staphylococci to intravascular catheters. J Med Microbiol 1989:28: 249-257.

9. Barrett S. Staphylococcal infection of plastic inserts: a method to measure staphylococcal adhesion. Br J Clin Pract 1983 : 37 Suppl 25: 81-85

10. Martinez-Martinez L. Pascual A. Perea EJ. Kinetics of adherence of mucoid and non-mucoid Pseudomonas aeruginosa to plastic catheters. $J$ Med Microbiol $1991: 34: 7-12$

11. Pratt-Terpstra I. Weerkamp A. Busscher $\mathrm{HJ}$. On a relation between interfacial free energy-dependent and noninterfacial free energy-dependent adherence of oral streptococci to solid substrata. Curr Microbiol 1988; 16: 311-313.

12. Fletcher M. Loeb GI. Influence of substratum characteristics on the attachment of a marine pseudomonad to solid surfaces. Appl Entiron Microbiol 1979: 37: 67-72.

13. McEldowney S. Fletcher M. Effect of growth conditions and surface characteristics of aquatic bacteria on their at tachment to solid surfaces. J Gen Microbiol 1986: 132 $513-523$.
14. Hogt AH. Dankert J, Feijen J. Adhesion of coagulase-negative staphylococci with different surface characteristics onto a hydrophobic biomaterial. Antonie van Leeuwenhoek 1985 ; 51: $510-512$.

15. Christensen GD, Simpson WA, Younger JJ et al. Adherence of coagulase-negative staphylococci to plastic tissue culture plates: a quantitative model for adherence of staphylococci to medical devices. J Clin Microbiol 1985; 22: $996-1006$.

16. Rosenberg M, Gutnick D, Rosenberg E. Adherence of bacteria to hydrocarbons; a simple method for measuring cell surface hydrophobicity. FEMS Microbiol Lett 1980; 9 : 29-33.

17. Denyer SP, Hanlon GW, Davies MC, Gorman SP. Antimicrobial and other methods for controlling microbial adhesion and infection. In: Denyer SP, Gorman SP Sussman $M$ (eds) Microbial biofilms: formation and control. Society for Applied Bacteriology Technical Series no. 30. Oxford, Blackwell Scientific Publications. 1993: $147-165$.

18. Klotz ST. Role of hydrophobic interactions in microbial adhesion to plastics in medical devices. In: Doyle RJ, Rosenberg M (eds) Microbial cell surface hydrophobicity. Washington, American Society for Microbiology. 1990 107.

19. Rosenberg M, Kjelleberg S. Hydrophobic interactions: role in bacterial adhesion. Adv Microb Ecol 1986; 9: 353-393.

20. Gibbons RJ, Etherden I. Comparative hydrophobicities of oral bacteria and their adherence to salivary pellicles. Infect Immun 1983; 41: 1190-1196.

21. Hogt AH, Dankert J, Hulstaert CE, Feijen J. Cell surface characteristics of coagulase-negative staphylococci and their adherence to fluorinated poly(ethylenepropylene). Infect Immun 1986; 51: 294-301.

22. Espersen F, Wurr M, Corneliussen L et al. Attachment of staphylococci to different plastic tubes in vitro. $J$ Med Microbiol 1994; $\mathbf{4 0}: 37-42$

23. Wadstrom T. Hydrophobic characteristics of staphylococci role of surface structures and role in adhesion and host colonisation. In: Doyle RJ, Rosenberg M (eds) Microbia cell surface hydrophobicity. Washington, American Society for Microbiology. 1990; 315 . 